\title{
LETTER TO THE EDITORS: MISREPRESENTING ADAM SMITH'S MONETARY AND BANKING ANALYSES: A COMMENT ON NICHOLAS CUROTT'S INTERPRETATIONS
}

\author{
BY
}

JAMES AHIAKPOR

\begin{abstract}
Nicholas Curott attempts to correct some misrepresentations of Adam Smith's monetary and banking analyses. However, failing to recognize Smith's adoption of David Hume's quantity theory of price levels and the price-specie-flow mechanism, Smith's distinction between money and credit and their sources, and Smith's suggestion of real, rather than "fictitious," bills as safer for private bank lending, Curott denigrates Smith's theory of money and banking as inferior to some modern writers'. Curott also mischaracterizes Smith's money demand function, which is best represented as a rectangular hyperbola. I draw from the Wealth of Nations to correct Curott's misrepresentations of Smith's analyses.
\end{abstract}

\section{INTRODUCTION}

Nicholas Curott (2017; subsequent Curott references are to this source) attempts to correct some misinterpretations of Adam Smith's monetary and banking analyses. However, failing to read carefully Smith's writings and some earlier restatements of Smith's analyses, he rather deepens the misrepresentations. He does not recognize Smith's adoption of David Hume's price-specie-flow analysis; he denies Smith's adoption of the quantity theory of money; he attributes to Smith the wrong money demand curve; he misrepresents Smith's conception of money's short-run supply curve; he misses Smith's clear distinction between money and the circulating medium; and he incorrectly credits modern free-banking advocates with superiority of their analysis over Smith's. Curott also fails to clarify Smith's designation of real bills-of-exchange as safer for private bank lending, which principle framers of the Federal Reserve's lending policy

James C. W. Ahiakpor, Department of Economics, California State University, East Bay, Hayward, California, james.ahiakpor@csueastbay.edu. 
adopted in order to sustain its adherence to a gold-exchange standard. He thus misses correctly explaining the errors of the so-called real-bills doctrine's critics.

\section{ADAM SMITH AND DAVID HUME'S PRICE-SPECIE-FLOW MECHANISM}

Smith followed David Hume's price-specie-flow analysis. However, Smith's appears scattered instead of being as integrated as Hume's. This may explain the varied treatments of his monetary analysis by the likes of Jacob Viner, Lloyd Mints, Douglas Vickers, David Laidler, and Murray Rothbard. But a careful reading of Smith's Wealth of Nations establishes his adherence to most of Hume's monetary analysis; see, e.g., Samuel Hollander $(1973,1987)$ and James Ahiakpor (1999).

Smith explains specie flows between trading countries in response to their pricelevel differences. Countries with lower prices receive more money (specie) in return for exports while countries with higher prices pay out money for imports. Thus, "a country that has no mines of its own must undoubtedly draw its gold and silver from foreign countries" ([1776] 1976, 1, p. 456; see also p. 453; subsequent Smith references are to this source). Therefore, a trading country's short-run money supply curve is upward-sloping.

Curott (pp. 330-331) ${ }^{1}$ acknowledges Smith's specie-flow analysis but incorrectly denies he employs price-level variation as a causal link. But Smith argues, e.g.:

The continual importations from Peru and Brazil [into Spain and Portugal] exceed the effectual demand of those countries, and sink the price of those metals there below that in the neighbouring countries. If, on the contrary, in any particular country their quantity fell short of the effectual demand, so as to raise their price above that of the neighbouring countries, the government would have no occasion to take any pains to import them. (1, p. 457; italics added)

Curott also might have recognized Smith's employing the quantity theory had he not misrepresented Smith's money supply-and-demand curves as being perfectly inelastic. Such curves do not cross.

Smith's demand for money is for some quantity to hold in readiness to make purchases, which thus must vary positively with the level of prices. Smith (1, pp. 26-27) explains:

In order to avoid the inconveniency of [barter], every prudent man in every period of society, ..., must naturally have endeavoured to manage his affairs in such a manner, as to have at all times by him, besides the peculiar produce of his own industry, a certain quantity of some one commodity or other, such as he imagined few people would be likely to refuse in exchange for the produce of their industry.

Furthermore, "Any increase in the quantity of commodities annually circulated within the country, while that of the money which circulated them remained the same, would, ..., produce many other important effects, besides that of raising the value of money"

\footnotetext{
${ }^{1}$ Curott refers to Rothbard's indictment of Smith's monetary analysis, to which Ahiakpor (1999) provides contrary evidence, but ignores that correction.
} 
(1, p. 378; italics added). Therefore, Smith's money demand curve is a rectangular hyperbola, as Alfred Marshall ([1923] 1960, pp. 41, 282-284) explains. If Smith, the author of the self-interest axiom, by which our thoughtful actions are always in pursuit of our own betterment, contradicted himself with the claim that people hold a fixed nominal quantity of money, regardless of the level of prices, we need the evidence.

\section{SMITH'S DISTINCTION BETWEEN MONEY AND OTHER MEANS OF PAYMENT}

Following Hume, Smith defines money as specie and banknotes as "promissory notes" or "paper credit" (1, p. 310). Thus, unlike the modern commingling of bank credit with money, such as M1 or M2, and claiming that the emission of bank credit increases "the money supply," Smith argues the inability of banks to enlarge the circulating medium for long when banknotes are redeemable in specie. Banks extended loans either in the form of money or its substitutes (banknotes). Bank owners' capitals and the public's savings were the sources of funds for lending. Deposited savings withdraw money from circulation while bank lending reinserts it.

But when banks issue notes as loans beyond that consistent with the quantity of money and the public's volume of savings, prices rise: “An increase of paper money, ..., by augmenting [the circulating medium], and consequently diminishing the value of the whole currency, necessarily augments the money price of commodities" (Smith, 1, p. 345). The quantity theory and price-specie-flow mechanism are set in motion: the demand for imports increases and exports contract. The "excess" notes are redeemed in specie from their issuers to pay for imports. That is Smith's process of the reflux of paper money. Henry Thornton's criticism of Smith, which Curott (p. 338) approvingly cites, is thus misleading.

Following Thornton, Curott misattributes to Smith the argument that an excessive issue of paper money would cause "the supply of money [to be] greater than the effectual demand, but prices do not increase because the excess is not needed for domestic trade and does not circulate" (p. 324). Also, he claims for Smith, "The issuance of banknotes ... causes an idle surplus of money to develop that no one wants to hold or spend," then declares Smith's analysis to be lacking "internal consistency" (p. 336).

Banknotes are held either because of their convenience in transportation or ease of storage; they are not in a "surplus." Obtained as credit, they are spent, almost immediately. Thus, Curott's attributing to Smith the claim that "extra money ... is a useless excess that lies idle and unemployed" (pp. 329, 344) appears a misinterpretation of Smith's (1, p. 462) argument: "Were [gold and silver] to be accumulated beyond the quantity [needed], their transportation is so easy, and the loss which attends their lying idle and unemployed so great, that no law could prevent their immediately being sent out of the country."

\section{SMITH AND THE SO-CALLED REAL-BILLS DOCTRINE}

Curott seeks to absolve Smith of having originated the so-called real-bills doctrine, given its criticism by the likes of Lloyd Mints, Milton Friedman, Friedman and Anna 
Schwartz, Thomas Humphrey, and David Laidler. Curott's defense of Smith includes: "Smith says ... the supply of money, including banknotes, is forced to regulate itself to a fixed demand" (p. 340) and "Smith's intention was not to devise a policy for accommodating the fluctuating needs of business and prevent inflation" (p. 341). Not helpful.

A helpful clarification is to restate Smith's own argument against its mischaracterizations by critics of US Federal Reserve actions during the Great Depression (1930 to 1933). Smith (1, pp. 328-337) suggests that banks' short-term lending on real bills-ofexchange is less likely to result in their bankruptcy than lending on "fictitious" or "circulating" bills. The latter are bills drawn and redrawn by borrowers, not upon goods sold. Thus, one is "a bill drawn by a real creditor upon a real debtor"; the other, "a bill for which there was properly no real creditor but the bank which discounted it; nor any real debtor but the projector who made use of the money" (p. 332). Smith (1, pp. 333-337) illustrates the point with the Ayr bank's ruin in Scotland from having loaned on fictitious bills.

Besides, increased production tends to lower prices until more money flows in. Banks' lending more of their specie reserves on real bills would thus sustain the domestic price level, short-circuiting the price-specie-flow process; not even Hume ([1752] 1955, pp. 37-38) argues that domestic prices adjust instantaneously to international specie flows or that "the price level was determined exogenously" (Curott, p. 339). Smith (1, p. 458) explains their gradual change.

To preserve the value of its money, the Federal Reserve Act (1913) required that it base currency creation $40 \%$ upon gold and additional collateral of $60 \%$ in either gold or eligible paper or "real bills." Henry Thornton ([1802] 1965, pp. 85-87) appears to have started the current misunderstanding with his claiming that "real" bills could be discounted multiple times in a year, ignoring the financial security aspect of Smith's suggestion. Thomas Humphrey (1982) follows Thornton's argument to claim that the Fed's lending on the real bills would generate a never-ending inflation, even as the experience of the Great Depression was that of price deflation. ${ }^{2}$ Others criticize the Fed for having followed the doctrine and not increased its currency sufficiently to have prevented the deflation.

\section{SMITH AND MODERN FREE-BANKING ADVOCATES}

Curott claims Smith's analysis of banking was "marred by a flawed monetary theory" (p. 341), yet was a crude precursor of modern free-banking arguments by the likes of George Selgin and Lawrence White, because Smith argued a "fixed channel of circulation." But Smith's "channel of circulation" is the economy's real production, which is not fixed. Also, modern free-banking advocates claim that an uninhibited issuing of private banknotes would be self-regulating and assure a more efficient and stable financial system than one in which a central bank issues fiat money. Smith instead recognized the greater possibility of fraud by banks, if allowed to issue small-denominations notes,

${ }^{2}$ Humphrey's model also does not recognize savings as the principal source of bank loans or the pricedeflation effect of increased production. 
and recommended their prohibition (1, p. 343). He acknowledged the violation of "natural liberty" the prohibition entails, but justified it on preserving "the security of the whole society." He likened its wisdom to the "obligation of building party walls, in order to prevent the communication of fire" (1, p. 345).

Rather than Smith's having provided a "crude" model for modern free-banking advocates, the moderns appear not to have learned sufficiently from his well-developed theory of money and banking. Modern central banks have replaced specie with their notes, and commercial banks still may lend such notes or extend credit with checkable deposits or electronic transfers.

\section{CONCLUSION}

Smith followed Hume's price-specie-flow mechanism, the quantity theory of money, and the distinction between money and its (credit) substitute means of payment and their sources, and suggested a lending principle for banks' own security. Hume, in contrast, was skeptical of the benefits of bank lending through issuing "counterfeit money" (Hume [1752] 1955, p. 35). Rather than having clarified Smith's analyses, Curott's claims deepen their misrepresentation. Claims of perfectly inelastic money supply and demand curves for Smith are particularly unwarranted.

\section{REFERENCES}

Ahiakpor, James C. W. 1999. "Did Adam Smith Retard the Development of Economics? A Critique of Murray Rothbard's Interpretation.” Independent Review 3, 3 (Winter): 355-383.

Curott, Nicholas A. 2017. "Adam Smith's Theory of Money and Banking." Journal of the History of Economic Thought 39, 3 (September): 323-347.

Hollander, Samuel. 1973. The Economics of Adam Smith. Toronto: University of Toronto Press.

- 1987. Classical Economics. New York: Basil Blackwell.

Hume, David. [1752] 1955. Hume's Writings on Economics. Edited by E. Rothwein. Edinburgh: Nelson.

Humphrey, Thomas. 1982. "The Real Bills Doctrine.” Economic Review (Federal Reserve Bank of Richmond) 68 (5): 3-33.

Marshall, Alfred. [1923] 1960. Money, Credit and Commerce. New York: Augustus M. Kelley.

Smith, Adam. [1776] 1976. The Wealth of Nations. Edited by E. Cannan. Volumes 1 and 2. Chicago: University of Chicago Press.

Thornton, Henry. [1802] 1965. Paper Credit in Great Britain. Edited by F. A. Hayek. New York: Augustus M. Kelley.

Viner, Jacob. 1937. Studies in the Theory of International Trade. New York: Harper. 